\title{
Did genome duplication drive the origin of teleosts? A comparative study of diversification in ray-finned fishes Francesco Santini ${ }^{1}$, Luke J Harmon ${ }^{2}$, Giorgio Carnevale ${ }^{3,4}$ and Michael E Alfaro*1
}

Address: ${ }^{1}$ Department of Ecology and Evolutionary Biology, University of California at Los Angeles, 651 Charles Young Dr. South, Los Angeles, CA 90095, USA, ²Department of Biology, University of Idaho, Moscow, ID 83844, USA, ${ }^{3}$ Dipartimento di Scienze della Terra, Universitá di Pisa, Via Santa Maria 53, 56126 Pisa, Italy and ${ }^{4}$ Museo di Storia Naturale e del Territorio, Via Roma 79, 56011, Calci, Italy

Email: Francesco Santini - santini@eeb.ucla.edu; Luke J Harmon - lukeh@uidaho.edu; Giorgio Carnevale - carnevale@dst.unipi.it; Michael E Alfaro* - michaelalfaro@ucla.edu

* Corresponding author

Published: 8 August 2009

BMC Evolutionary Biology 2009, 9:194 doi:10.1।86/147I-2/48-9-194
Received: 9 December 2008

Accepted: 8 August 2009

This article is available from: http://www.biomedcentral.com/I47I-2/48/9//94

(C) 2009 Santini et al; licensee BioMed Central Ltd.

This is an Open Access article distributed under the terms of the Creative Commons Attribution License (http://creativecommons.org/licenses/by/2.0), which permits unrestricted use, distribution, and reproduction in any medium, provided the original work is properly cited.

\begin{abstract}
Background: One of the main explanations for the stunning diversity of teleost fishes $(\sim 29,000$ species, nearly half of all vertebrates) is that a fish-specific whole-genome duplication event (FSGD) in the ancestor to teleosts triggered their subsequent radiation. However, one critical assumption of this hypothesis, that diversification rates in teleosts increased soon after the acquisition of a duplicated genome, has never been tested.
\end{abstract}

Results: Here we show that one of three major diversification rate shifts within ray-finned fishes occurred at the base of the teleost radiation, as predicted by the FSGD hypothesis. We also find evidence for two rate increases that are much younger than the inferred age of the FSGD: one in the common ancestor of most ostariophysan fishes, and a second one in the common ancestor of percomorphs. The biodiversity contained within these two clades accounts for more than $88 \%$ of living fish species.

Conclusion: Teleosts diversified explosively in their early history and this burst of diversification may have been caused by genome duplication. However, the FSGD itself may be responsible for a little over $10 \%$ of living teleost biodiversity. $~ 88 \%$ of species diversity is derived from two relatively recent radiations of freshwater and marine fishes where genome duplication is not suspected. Genome duplications are a common event on the tree of life and have been implicated in the diversification of major clades like flowering plants, vertebrates, and gnathostomes. However our results suggest that the causes of diversification in large clades are likely to be complex and not easily ascribed to a single event, even a dramatic one such as a whole genome duplication.

\section{Background}

With approximately 28,872 species, teleost fishes constitute the dominant radiation of vertebrates on our planet [1]. One common explanation for this diversity is that a complete duplication of the entire genome [2] facilitated teleost diversification. This event is also known as the fish specific genome duplication, or FSGD [3]. Many studies have corroborated the occurrence of the genome duplication event [3-7], and several workers have hypothesized that the FSGD enabled the subsequent explosive diversifi- 
cation of teleosts by providing massive opportunities for evolutionary experimentation via gene duplication and decoupling [3-6]. This hypothesis, which we refer to as FSGD-FD (FSGD-facilitated diversification) has never been quantitatively tested.

The fact that teleosts contain over $99 \%$ of the total diversity found in ray-finned fishes might be taken as evidence that the diversification rate in teleosts is higher than in their close relatives. However a closer examination of species richness within teleosts reveals that the history of their diversification has been complex. Several teleost orders possess low species richness (Table 1), while the bulk of the biodiversity is concentrated in two large groups: the Ostariophysi, an almost exclusively freshwater clade that includes carps, danios, piranhas, and catfish, and the Perciformes (or perch-like fishes), a group of spiny-rayed fish that includes the majority of coastal and pelagic marine fish as well as some large freshwater lineages like cichlids and perches. Both of these groups appear in the fossil record 150-250 My after the estimated time of the FSGD $[3,7,8]$. One central prediction of the FSGDFD hypothesis is that the diversification rate accelerated with the origin of teleosts. An alternative hypothesis is that major rate shifts are more recent, and correspond to the appearance of the species-rich teleost subclades described above. If true, this alternative hypothesis would suggest that the FSGD did not play a major role in generating fish biodiversity, due to the long interval between genome duplication and accelerated diversification.

Recently, a number of molecular timescales for ray-finned fishes have been published. However most of these studies sampled a limited number of taxa and used relatively few fossil calibrations [7,9-11], making it difficult to date the origin of more than a few major actinopterygian crown groups. Here we present a large scale molecular timescale for actinopterygians that allows us to estimate the divergence times of most major lineages as well as the origin of many crown groups within them. We used this timescale along with information about taxonomic richness of unresolved actinopterygian clades to test the hypothesis that teleosts experienced an increase in diversification rates as predicted by the FSGD with a recently developed comparative method, MEDUSA (Modeling Evolutionary Diversification Using Stepwise AIC) ([16]; Additional file 1).

\section{Results \\ Timetree}

We downloaded and aligned 227 vertebrate RAG1 sequences from GenBank (221 actinopterygians, 4 sarcopterygians, 2 elasmobranchs, Additional File 2), and used Bayesian methods to infer divergence times with the ages of 44 clades constrained by fossils (Table 2). Our timetree
(Fig 1, 2, 3) is the most comprehensive divergence time study of actinopterygians to date: it includes representatives of 39 of the 44 orders of ray-finned fish and 127 teleost families (which, taken together, represent over $80 \%$ of the total teleost species diversity); in addition, many of the 45 fossil calibration points used in this study, identified after a comprehensive review of the actinopterygian fossil record, have never before been integrated in a divergence time analysis (Additional file 3 ).

Among the Actinopterygii, the crown ray-finned fishes (Fig. 1, node 4) have a mean age of 298 Ma (with a $95 \%$ High Posterior Density, HPD: 284 to $337 \mathrm{Ma}$ ). This is approximately $100 \mathrm{My}$ older than the oldest fossil, but also 100 My younger than recent mitogenomic studies [9-11]. The key node in this study is the most recent common ancestor of teleosts (Fig. 1, node 6). We found that teleosts separated from their sister taxon, which in our analysis is a clade formed by gars and the bowfin (from here onwards we refer to this clade as Holostei) about 230 Ma, (95\% HPD: 225-243 Ma), and radiated $193 \mathrm{Ma}$ (95\% HPD: 173-214 Ma). Our age estimate overlaps with the revised estimate for the FSGD of Hurley et al. [7] (226-316 Ma) but is not congruent with earlier estimates of 300-350 Ma based on less complete sampling [4,6,12]. The short fuse of $37 \mathrm{My}$ between the origin of crown neopterygians and the origin of crown teleosts also suggests a relatively brief window of time for the occurrence of the FSGD. Within teleosts, we found that the two largest clades are both Cretaceous in origin. Crown Ostariophysi appeared $128 \mathrm{Ma}$ (95\% HPD: 125-134 Ma) (Fig. 1), and the crown Percomorpha (which differs from the Percomorpha of Nelson [13] because it includes also the Atherinomorpha, and includes over $50 \%$ of all teleosts) appeared $104 \mathrm{Ma}$ (95\% HPD: 93-115 Ma) (Fig. 2).

Our estimated ages for both the origin of the teleosts, as well as for the main splits among their major lineages (Table 3), are much younger than those inferred in mitogenomic studies $[7,11]$, but are in fairly close agreement with dates provided by time-calibrated nuclear gene divergences in Hurley et al. [7]. This discrepancy might be due to an overall higher rate of evolution in mitochondrial genomes as discussed by Hurley et al. [7]. Within the more derived teleosts, our age estimates are generally younger than those previously published, but are in relatively good agreement with Inuoe et al. [9] for the origin of the acanthomorphs, with largely overlapping 95\% HPDs in both studies. The age of two important percomorph clades, the cichlids and the tetraodontiforms, are drastically different between our study and previous work $[10,11]$ (Fig. 3). The crown cichlids appear to have originated $57 \mathrm{Ma}$, with the split between the African and Neotropical lineages only 49 My old, dates that are consistent with those inferred by Genner et al. [14]. These ages 
Table I: Ray-finned fish Species Richness

\begin{tabular}{|c|c|}
\hline Lineage name in Fig. 4 & Richness Fishbase [I] \\
\hline Elasmobranchi & 970 \\
\hline Latimeriidae & 2 \\
\hline Dipnoi & 3 \\
\hline Polypteriformes & 18 \\
\hline Chondrostei & 30 \\
\hline Holostei & 8 \\
\hline Elopomorpha & 924 \\
\hline Osteoglossomorpha & 228 \\
\hline Clupeomorpha & 382 \\
\hline Denticipidae & 1 \\
\hline Gonorynchiformes & 37 \\
\hline Cypriniformes & 3665 \\
\hline Characiformes & 1847 \\
\hline Siluriformes & 3214 \\
\hline Gymnotiformes & 148 \\
\hline Osmeriformes & 44 \\
\hline Galaxiiformes & 51 \\
\hline Stomiiformes & 406 \\
\hline Argentiniformes & 197 \\
\hline Salmoniformes & 205 \\
\hline Esociformes & 13 \\
\hline Myctophiformes & 254 \\
\hline Aulopiformes & 244 \\
\hline Percopsiformes+Gadiiformes & 610 \\
\hline Polymixiiformes & 10 \\
\hline Zeiformes & 32 \\
\hline Lampriformes & 24 \\
\hline
\end{tabular}


Table I: Ray-finned fish Species Richness (Continued)

\begin{tabular}{lc}
\hline Beryciformes [includes Stephanoberyciformes] & 233 \\
\hline Ophidiiformes & 460 \\
\hline Percomorpha & 15639
\end{tabular}

Ray-finned fish species richness taken from Fishbase [I].

appear to rule out a major role of the breakup of Gondwana [which dates to the Cretaceous] in determining the present distribution of this group. The Tetraodontiformes, the group that includes the pufferfish, an important model for vertebrate genomics, originated $\sim 65 \mathrm{Ma}$, towards the end of the Cretaceous. This age is in agreement with the estimate based the previous analysis of a multigene dataset of Alfaro et al. [15], but is almost 100 Ma younger than Yamanoue et al.'s estimate based on mitogenomes [10].

\section{Diversification rate study}

To test whether diversification rate shifts supports the FSGD-diversification hypothesis, we applied a recently developed comparative method [MEDUSA, Modeling Evolutionary Diversification Using Stepwise AIC ([16], Additional file 1) to a 'diversity tree' derived from both the chronogram and species richness data compiled from the literature [Fig. 4]. Our stepwise procedure, based on the flexible rate model of Rabosky et al. [17], integrates both phylogenetic and taxonomic data [Fig. 4], and involves the assignment of rate shifts [both birth and death rates] to the optimal branches on the phylogeny with unresolved tips until additional rate changes do not substantially improve the AIC score. We tabulated the total species richness of actinopterygians, and partitioned it among representative stem lineages in our phylogeny. We pruned the chronogram down to representatives of each stem lineage with taxonomic information and estimated diversification statistics for the tree under the assumption of rate homogeneity across lineages. Then we tested for rate heterogeneity across lineages by implementing MEDUSA, to identify lineages representing significant departures from an expected background of diversification [16].

Our study reveals that actinopterygian biodiversity has been profoundly shaped by four diversification events. The most statistically significant of these occurred at the base of modern teleosts, as predicted by the FSGD-FD hypothesis, and involved a four-fold increase in net diversification rates [net rate $r=$ birth rate - death rate] over the background rates estimated from the closest evolutionary relatives of teleosts. Additionally we find evidence for secondary rate increases in two lineages. The first of these preceded the radiation of percomorph fishes comprising most of the diversity of acanthomorphs or spiny-rayed fishes [13], including most of the coral reef-associated teleost families as well as most other marine fish diversity. The second increase preceded the radiation of a clade containing most ostariophysans, including the cypriniforms (carps and minnows), characiforms (pirhanas) and siluriforms (catfish). The final rate shift is a deceleration which gave rise to the denticled herring, the sole member of the family Denticipitidae, an ancient lineage that is the sister taxon of the Ostariophysi.

The teleost rate shift is characterized by a 3.7 fold increase in the rate of net diversification. Surprisingly, despite a net increase in diversification rate, estimated extinction rates in teleosts is higher than in nonteleosts (death rate, $\mathrm{d}_{\text {teleosts }}$ $\left.=6.98 \times 10^{-5}, \mathrm{~d}_{\text {nonteleosts }}=1.21 \times 10^{-5}\right)$. This contradicts suggestions that genome duplication in teleosts would have contributed to their diversification by making them more resistant to extinction [18]. Instead, turnover $(e$, the ratio of death to birth rate) is 1.5 times higher in teleosts than in non-teleosts. In comparison, the rate shift that gave rise to the percomorphs was less pronounced with a net diversification rate 1.98 times greater than the teleost rate. The rate shift leading to the ostariophysans reveals a period of increased volatility in the history of actinopterygians. Birth rates increased by more than 2.6 fold over teleost birth rates, but this rise in cladogenesis was checked by a substantial increase in extinction rates. This resulted in turnover rates in ostariophysans that were 218 times higher than other teleosts. An increase in clade volatility may also have accompanied the increase in the percomorph diversification rate, but we were unable to calculate independent birth and death rates from the net diversification rate due to a lack of phylogenetic resolution within this large clade. In contrast to these three major rate accelerations, the shift underlying the denticled herring was characterized by a $\sim 12$ orders of magnitude decrease in net diversification rate. This result provides additional empirical evidence for the unusual nature of ancient clades of small size. These clades are too small and persist too long to be plausible outcomes under typical birth-death models unless the birth and death rates approach $0[19,20]$.

\section{Discussion}

Our study provides two lines of evidence in support of the FSGD-FD hypothesis. First, we find a significant increase in the diversification rate of teleosts. Second, the window 


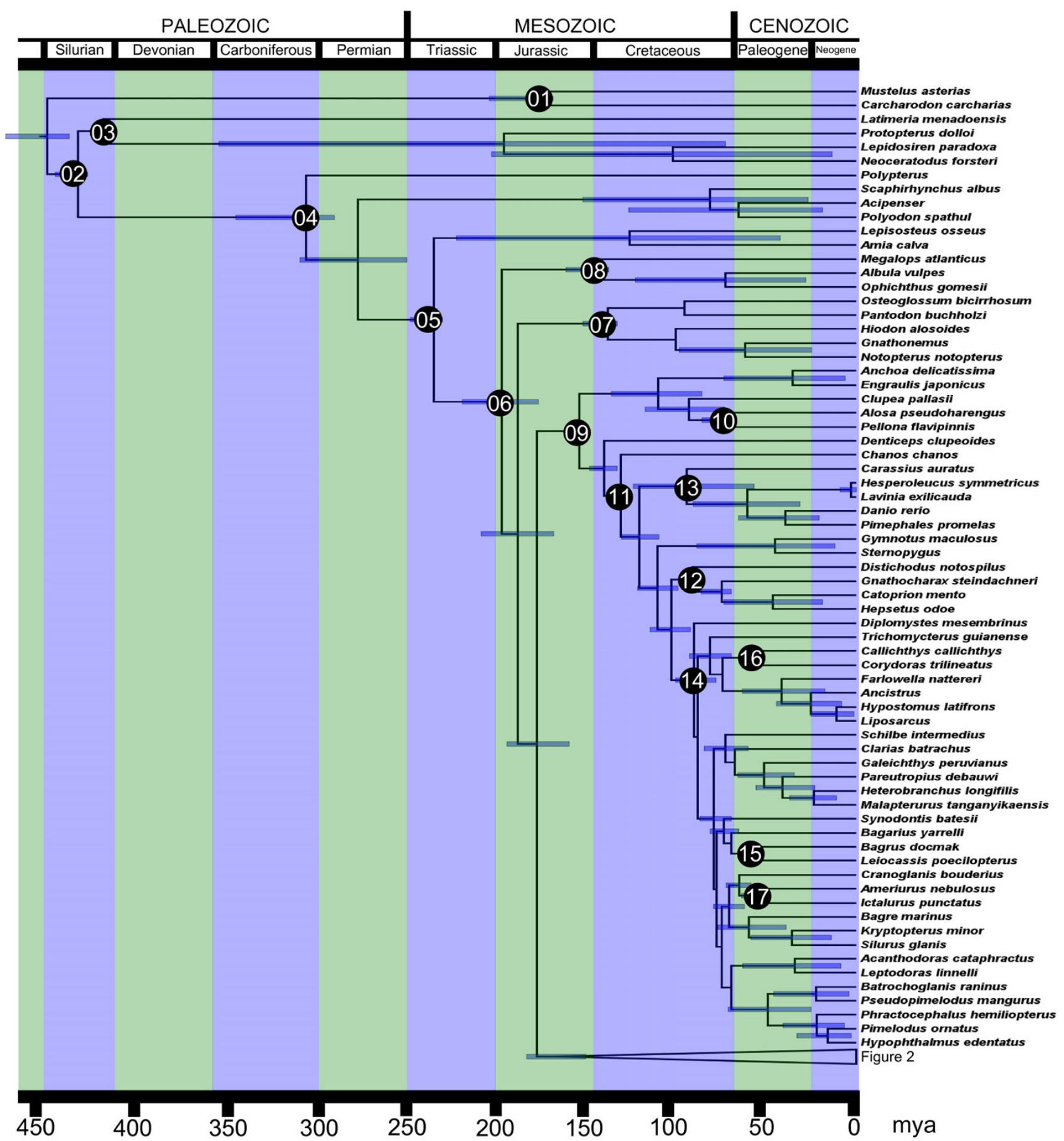

Figure I

Timetree of ray-finned fish. Timetree of ray-finned fish based on 227 RAG I sequences and 45 fossil calibration points. Includes taxa from Polypteriformes to Ostariophysi from Fig. 4. 


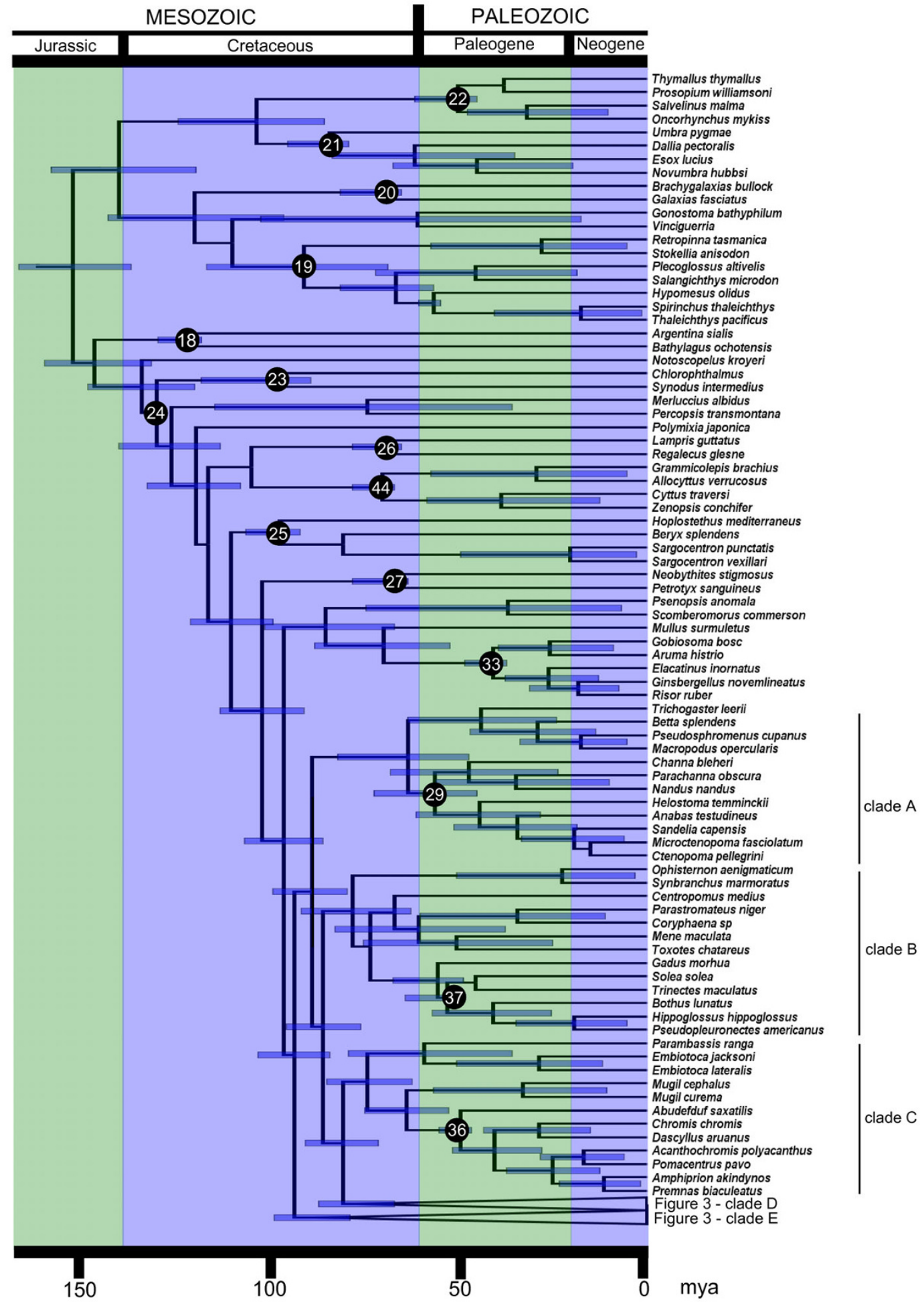

Figure 2

Timetree of ray-finned fish. Timetree of ray-finned fish based on 227 RAG I sequences and 45 fossil calibration points. Includes taxa from Esociformes to part of Percomorpha from Fig. 4. 


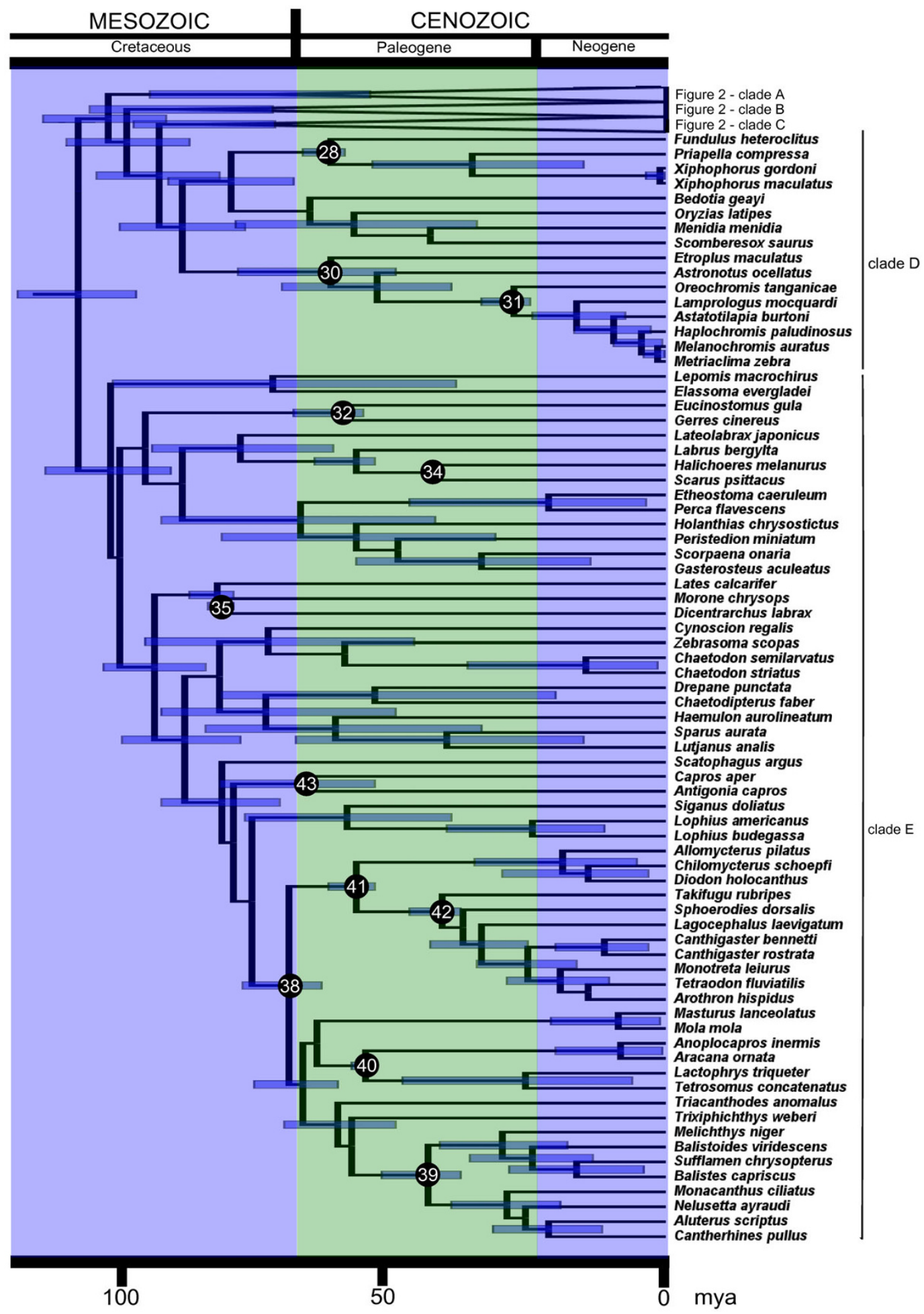

Figure 3

Timetree of ray-finned fish. Timetree of ray-finned fish based on 227 RAG I sequences and 45 fossil calibration points. Includes part of Percomorpha from Fig. 4. 
Table 2: Priors Used in Divergence Time Analysis

\begin{tabular}{|c|c|c|c|c|}
\hline Node & Name & Mean & $95 \%$ & Prior \\
\hline & Root & 428 & 505 & \\
\hline I & Elasmobranchii & 16 & 41 & $\begin{array}{l}\text { Offset } 165 \text {, means I.9, SD } \\
2.2\end{array}$ \\
\hline 2 & Osteichthyes & 418 & 505 & $\begin{array}{l}\text { Offset } 418, \text { mean } 1.21, \text { SD } \\
\text { I.98 }\end{array}$ \\
\hline 3 & Sarcopterygii & 407 & 505 & $\begin{array}{l}\text { offset } 407, \text { mean } 1.49, \text { SD } \\
\text { I.88 }\end{array}$ \\
\hline 4 & Actinopterygii & 284 & 420 & $\begin{array}{l}\text { Lognormal, offset } 284 \text {, mean I.9I, SD } \\
\text { I.83 }\end{array}$ \\
\hline 5 & Neopterygii & 225 & 284 & $\begin{array}{l}\text { offset } 225 \text {, mean I.I2, SD } \\
\text { I.8 }\end{array}$ \\
\hline 6 & Teleostei & 152 & 228 & $\begin{array}{l}\text { offset I52, mean I.30, SD } \\
1.94\end{array}$ \\
\hline 7 & Osteoglossomorpha & 130 & 152 & $\begin{array}{l}\text { offset } 130 \text {, mean } 1.0, \text { SD } \\
\text { I.27 }\end{array}$ \\
\hline 8 & Elopomorpha & 135 & 152 & $\begin{array}{l}\text { offset } 135 \text {, mean } 0.62, \text { SD } \\
\text { I. } 35\end{array}$ \\
\hline 9 & Ostarioclupeomorpha & 149 & 152 & $\begin{array}{l}\text { Offset } 149 \text {, mean } 0.1, \mathrm{SD} \\
0.6\end{array}$ \\
\hline 10 & Pristigasteroidea & 69 & 125 & $\begin{array}{l}\text { Offset } 69 \text {, mean } 1.48, \text { SD } \\
\text { I.55 }\end{array}$ \\
\hline 11 & Ostariophysi & 125 & 140 & $\begin{array}{l}\text { offset } 125 \text {, mean I.0, SD } \\
\text { I.04 }\end{array}$ \\
\hline 12 & Characiformes & 68 & 100 & $\begin{array}{l}\text { Offset } 68 \text {, mean I.5, SD } \\
\text { I.2 }\end{array}$ \\
\hline 13 & Cyprinidae & 49 & 100 & $\begin{array}{l}\text { Offset } 49 \text {, mean } 1.94, \text { SD } \\
1.2\end{array}$ \\
\hline 14 & Siluriformes & 73 & 83.5 & $\begin{array}{l}\text { offset } 73 \text {, mean } 0.7, \text { SD } \\
\text { I.0 }\end{array}$ \\
\hline 15 & Bagridae & 59 & 73 & $\begin{array}{l}\text { Offset 59, mean I.I, SD } \\
0.94\end{array}$ \\
\hline 16 & Callichthyidae & 55 & 73 & $\begin{array}{l}\text { Offset 55, mean I.4, SD } \\
0.94\end{array}$ \\
\hline 17 & Ictaluridae & 56 & 73 & $\begin{array}{l}\text { Offset 56, mean I.II, SD } \\
1.05\end{array}$ \\
\hline 18 & Argentiniformes & 127 & 152 & $\begin{array}{l}\text { Offset I27, mean I.0, SD } \\
\text { I.35 }\end{array}$ \\
\hline 19 & Osmeridae & 58.7 & 84 & $\begin{array}{l}\text { Offset 58.7, mean } 1.08, \text { SD } \\
\text { I.3I }\end{array}$ \\
\hline 20 & Galaxiidae & 70 & 124 & $\begin{array}{l}\text { Offset } 70 \text {, mean } 1.01, \text { SD } \\
\text { I.8I }\end{array}$ \\
\hline 21 & Esociformes & 85 & 152 & $\begin{array}{l}\text { offset } 85 \text {, mean } 1.9, \text { SD } \\
\text { I. } 4\end{array}$ \\
\hline
\end{tabular}


Table 2: Priors Used in Divergence Time Analysis (Continued)

\begin{tabular}{|c|c|c|c|c|}
\hline 22 & Salmoniformes & 48.6 & 125 & $\begin{array}{l}\text { offset } 48.6 \text {, mean I.54, SD } \\
\text { I.7 }\end{array}$ \\
\hline 23 & Aulopiformes & 96 & 128 & $\begin{array}{l}\text { Offset } 96 \text {, mean I.5, SD } \\
\text { I.2 }\end{array}$ \\
\hline 24 & Acanthomorpha & 99 & 122 & $\begin{array}{l}\text { Offset } 99, \text { mean } 0.1, \text { SD } \\
\text { I.85 }\end{array}$ \\
\hline 25 & Beryciformes & 99 & 122 & $\begin{array}{l}\text { Offset } 99 \text {, mean I.5, SD } \\
\text { I.03 }\end{array}$ \\
\hline 26 & Lampriformes & 70 & 98 & $\begin{array}{l}\text { Offset } 70 \text {, mean I.0, SD } \\
\text { I.42 }\end{array}$ \\
\hline 27 & Ophidiidae & 68 & 98 & $\begin{array}{l}\text { Offset } 68 \text {, mean I.28, SD } \\
1.29\end{array}$ \\
\hline 28 & Fundulidae vs Poeciilidae & 55 & 99 & $\begin{array}{l}\text { Offset } 55 \text {, mean I.2I, SD } \\
1.55\end{array}$ \\
\hline 29 & Channoidea & 48 & 84 & $\begin{array}{l}\text { Offset } 48 \text {, mean I.7I, SD } \\
\text { I.I4 }\end{array}$ \\
\hline 30 & Cichlidae & 46 & 84 & $\begin{array}{l}\text { offset } 46 \text {, mean } 1.5, \text { SD } \\
\text { I.3 }\end{array}$ \\
\hline 31 & African Cichlids & 23.3 & 84 & $\begin{array}{l}\text { Offset } 23.3 \text {, mean I.26, SD } \\
\text { I. } 49\end{array}$ \\
\hline 32 & Gerreidae & 52 & 84 & $\begin{array}{l}\text { offset } 52 \text {, mean I.16, SD } \\
\text { I.4 }\end{array}$ \\
\hline 33 & Gobiidae & 40 & 84 & $\begin{array}{l}\text { offset } 40 \text {, mean I.37, SD } \\
\text { I.47 }\end{array}$ \\
\hline 34 & Labridae & 50 & 84 & $\begin{array}{l}\text { offset } 50 \text {, mean } 0.9, \text { SD } \\
\text { I.6 }\end{array}$ \\
\hline 35 & Moronidae & 74 & 84 & $\begin{array}{l}\text { offset } 74 \text {, mean } 0.5, \text { SD } \\
\text { I.I }\end{array}$ \\
\hline 36 & Pomacentridae & 50 & 84 & $\begin{array}{l}\text { offset } 50 \text {, mean I.24, SD } \\
1.39\end{array}$ \\
\hline 37 & Pleuronectiformes & 52 & 98 & $\begin{array}{l}\text { offset } 52 \text {, mean } 1.28, S D \\
1.55\end{array}$ \\
\hline 38 & Tetraodontiformes & 59 & 98 & $\begin{array}{l}\text { offset } 59 \text {, mean } 0.8, \text { SD } \\
1.75\end{array}$ \\
\hline 39 & Balistoidea & 35 & 50 & $\begin{array}{l}\text { offset } 35 \text {, mean } .9, \text { SD } \\
\text { I.I }\end{array}$ \\
\hline 40 & Ostracioidea & 50 & 70 & $\begin{array}{l}\text { offset } 50 \text {, mean } 0.53, \text { SD } \\
\text { I. } 5\end{array}$ \\
\hline 41 & Tetraodontoidea & 50 & 70 & $\begin{array}{l}\text { Offset } 50 \\
\text { mean I.0, SD } \\
1.22\end{array}$ \\
\hline 42 & Tetraodontidae & 35 & 50 & $\begin{array}{l}\text { offset } 35 \text {, mean I.0, SD } \\
\text { I.04 }\end{array}$ \\
\hline 43 & Caproidae & 50 & 99 & $\begin{array}{l}\text { offset } 50 \text {, mean I.5I, SD } \\
\text { I.44 }\end{array}$ \\
\hline 44 & Zeiformes & 72 & 98 & $\begin{array}{l}\text { offset } 72 \text {, mean I.0I, SD } \\
\text { I.37 }\end{array}$ \\
\hline
\end{tabular}


Table 3: Divergence time estimates of focal ray-finned fish nodes

\begin{tabular}{|c|c|c|c|}
\hline Name of the split & Mean Age this study & $95 \%$ age this study & Other study ages \\
\hline Condrichthyes vs. Osteichthyes & 440 & & \\
\hline MRCA of Neoselachii & 178 & 165 to 200 & \\
\hline MRCA of Osteichthyes & 423 & 418 to 435 & 415 to $524[10]$ \\
\hline MRCA of Sarcopterygii & 409 & 407 to 415 & \\
\hline MRCA of Actinopterygii & 299 & 284 to 337 & $\begin{array}{l}397 \text { to } 478 \mathrm{mit} \text { [7]; } \\
374 \text { to } 448 \text { [9] }\end{array}$ \\
\hline MRCA of Actinopteri & 271 & 244 to 302 & $\begin{array}{l}348 \text { to } 391 \text { nuc } \\
\text { [7]; } 346 \text { to } 391 \\
\text { mit [7]; } 337 \text { to } \\
413 \text { [9] }\end{array}$ \\
\hline MRCA of Neopterygii & 230 & 225 to 243 & $\begin{array}{l}295 \text { to } 372 \text { nuc[7]; } \\
327 \text { to } 378 \text { mit }[7] \text {; } \\
340 \text { to } 442[10]\end{array}$ \\
\hline MRCA of Teleostei & 193 & 173 to 214 & $\begin{array}{l}268 \text { to } 326 \mathrm{mit}[7] \\
295 \text { to } 372 \text { [9] }\end{array}$ \\
\hline MRCA of Osteoglossomorpha & 135 & 130 to 148 & 22 I to 283 mit [7]; \\
\hline MRCA of Elopomorpha & 140 & 135 to 158 & 210 to $272 \mathrm{mit}[7]$ \\
\hline MRCA of Ostarioclupeomorpha & $|5|$ & 149 to 153 & $\begin{array}{l}\text { 1 } 92 \text { to } 255 \text { mit }[7] \\
242 \text { to } 332 \text { [10]; } \\
204 \text { to } 275 \text { [9] }\end{array}$ \\
\hline MRCA of Clupeomorpha & 108 & 84 to 133 & \\
\hline MRCA of Ostariophysi & 128 & 125 to 134 & \\
\hline MRCA of Cypriniformes & 92 & 56 to 123 & \\
\hline MRCA of Characiformes & 80 & 68 to 84 & \\
\hline MRCA of Siluriformes & 88 & 77 to 98 & \\
\hline MRCA of Euteleostei & 164 & 147 to 180 & $\begin{array}{l}\text { I } 82 \text { to } 244 \text { mit }[7] \\
240 \text { to } 326[10] \\
\text { I } 97 \text { to } 267[9]\end{array}$ \\
\hline MRCA of Salmoniformes & 54 & 49 to 66 & \\
\hline MRCA of Esociformes & 91 & 85 to 103 & \\
\hline MRCA of Galaxiiformes & 74 & 70 to 87 & \\
\hline MRCA of Acanthomorpha & 136 & 122 to 151 & $\begin{array}{l}\text { I } 25 \text { to } 186 \text { mit }[7] \\
191 \text { to } 264[10] \\
\text { I } 30 \text { to } 191 \text { [9] }\end{array}$ \\
\hline MRCA of Zeiformes & 76 & 72 to 84 & \\
\hline
\end{tabular}


Table 3: Divergence time estimates of focal ray-finned fish nodes (Continued)

\begin{tabular}{|c|c|c|c|}
\hline MRCA of Lampridiformes & 7 & 70 to 84 & \\
\hline MRCA of Beryciformes & 105 & 99 to 114 & \\
\hline MRCA of Percomorpha & 104 & 93 to 115 & \\
\hline MCRA of Caproidae & 61 & 50 to 77 & \\
\hline MRCA of Cichlidae & 57 & 46 to 73 & 72 to $108[11]$ \\
\hline African vs. American cichlids & 49 & 37 to 66 & \\
\hline MRCA of Atherinomorpha & 74 & 64 to 85 & \\
\hline MCRA of Pomacentridae & 53 & 50 to 59 & \\
\hline MCRA of Moronidae & 75 & 74 to 78 & \\
\hline MCRA of Labridae & 53 & 50 to 60 & \\
\hline MCRA of Gobiidae & 44 & 40 to 52 & \\
\hline MRCA of Tetraodontiformes & 66 & 59 to 76 & 124 to $184[10]$ \\
\hline MRCA of Tetraodontidae & 37 & $35.09,41.06$ & $\begin{array}{l}55 \text { to } 86[111] ; 57 \\
\text { to } 94[10]\end{array}$ \\
\hline MRCA of Balistoidea & 62 & $55.60,71.78$ & 95 to $146[10]$ \\
\hline MCRA of Pleuronectiformes & 57 & 52 to 69 & \\
\hline
\end{tabular}

Ages are in millions of years.

in time between the split of teleosts and their sister taxon, the Holostei (230 Ma, 95\% HPD:225-243 Ma, Fig. 1) and the subsequent radiation of crown teleosts (193 Ma, 95\% HPD:173-214 Ma, Fig. 1) overlaps with the estimated age of the genome duplication itself (316-226 Ma) derived from dating of gene paralogs [7]. Furthermore, since teleost diversification is characterized by increases in the birth rate and not by decreases in the death rate (Fig. 4), our study suggests that genome-facilitated mechanisms of divergence, like lineage-specific nonfunctionalization $[5,21]$, have played a larger role in teleost diversification than extinction resistance imparted by functional redundancy [18].

Our results also caution against the broad interpretation of the FSGD as the primary explanation for extant teleost diversity, of which approximately $\sim 88 \%$ derives from the secondary diversification events in the percomophs and ostariophysans. One limitation of MEDUSA is that the assignment of rate shifts is limited to the level of phylogenetic resolution. Thus, the rate shifts leading to the ostariophysans and percomorphs might reflect a series of rate changes within these unresolved groups. As the teleost tree of life is uncovered, it will become possible to more precisely identify subclades or time intervals where diversification rates have changed. However given these caveats, we suggest that the radiation of teleosts is best understood as consisting of at least three pulses. Initial diversification may have been facilitated by mechanisms related to the FSGD $[5,21]$, though further studies are needed to clarify how genome duplication can lead to sustained, elevated rates of diversification within a clade.

The second pulse (or series of pulses), the diversification within the largely freshwater ostariophysans, occurred about 100 My after the FSGD and coincides with the breakup of the supercontinent Gondwana during the Cretaceous. This geologic upheaval may have created opportunities for ecological diversification by creating new environments. Although many percomorph stem lineages also appear at this time, both the fossil record [8] and this molecular study suggest that the third pulse (or series of pulses) of teleost diversification occurred mostly in the Paleogene (65 to $23 \mathrm{Ma}$ ). Possible triggers of increased percomorph diversification include the establishment of scleractinian coral reefs and other tropical shallow water 


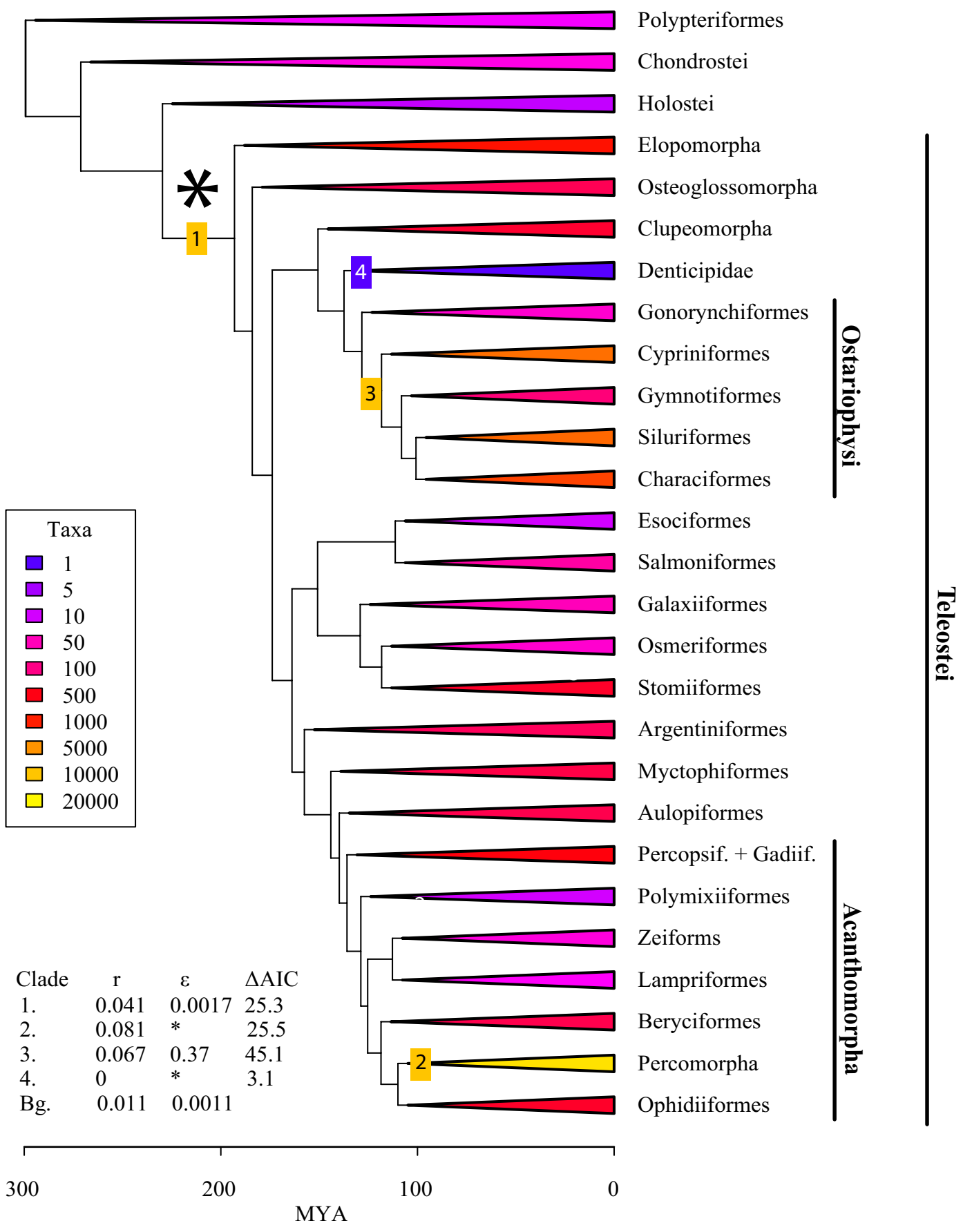

Figure 4

Diversity tree for analyses of lineage diversification in ray-finned fish. Diversity tree for analyses of lineage diversification in ray-finned fish. Clades from Fig. I, 2, 3 are collapsed to 27 representative stem lineages and colored by extant species diversity. Clades with unusual diversification rates are denoted with numbers; yellow and blue numbers denote exceptionally fast and slow rates respectively, compared to background rates. Estimates for net diversification rate $(r=b-d)$ and relative extinction rate $(e=d / b)$ are included in the lower right table. Asterisk indicates FSGD event. Abbreviations is figure as follows: Percopsif.: Percopsiformes, Gadiif.: Gadiiformes. 
habitats like sea grasses [15,22], the fragmentation of the marine biotas due to geological events such as the progressive closing of the Tethys sea [23], sea-level fluctuations [24], and the establishments of steeper temperature gradients across the world's oceans, primarily due to the rearrangement of oceanic currents [25].

\section{Conclusion}

Whole genome duplications are not uncommon in the tree of life and have been implicated in the diversification of other large clades, including most flowering plants (eudicots) and vertebrates $[18,26]$. Without quantitative comparison of diversification rates, however, it is difficult to identify the correlates of an evolutionary radiation, genomic or otherwise. The approach outlined here provides a mean for testing the central predictions of macroevolutionary hypotheses, including those linked to genome duplications, and represents an important step towards identifying the correlates of evolutionary radiations. Theoretical explanations of how genome duplication may lead to speciation have been proposed [27], and a number of examples are now known in which a genome duplication has been shown to have been linked to rounds of cladogenesis in yeasts and flowering plants $[28,29]$. However, additional work that elucidates the interplay between genomic isolating mechanisms and ecological opportunity is needed to more completely evaluate the role of genome duplication in shaping patterns of biodiversity.

\section{Methods}

\section{Timetree inference}

RAG1 sequences for 225 species of bony fish (including three species of lungfish, one species of coelacanths and 221 species of ray-finned fish), and two species of sharks, which we used as outgroups, were downloaded from GenBank (Additional file 2). The sampling was selected in order to both maximize the number of taxonomic groups that we could include in our analysis, and the number of fossil calibration points that could be assigned to the phylogeny. Sequences were aligned automatically using ClustallW [30], and the alignment was then refined by eye using MEGA 4 [31]. A survey of the fossil fish literature allowed us to identify 45 calibration points that were used to date 44 clades identified in the tree as well as the root of the tree (Additional file 3). We used BEAST v 1.4.6 [32] to estimate divergence times under a model of uncorrelated but log-normally distributed rates. We assigned soft upper bounds to the prior distributions of all fossil calibrations using log-normal distributions as described in Table 2. We specified a Yule prior on the rates of cladogenesis. The data set was assumed to have evolved under a GTR model with invariant sites and gamma-distributed rate heterogeneity. We constrained the monophyly of a number of groups in order to reflect generally accepted phylogenetic relationships. Five independent analyses of 20,000,000 generations each were run. Output from each run was analyzed using TRACER 1.4 [32]; $25 \%$ of the trees were discarded as burnin, and the remaining were combined using TreeAnnotator 1.4.6 to produce the timescale.

\section{Diversification rate analysis}

MEDUSA [16] is an extension of the flexible rate shift model introduced by Rabosky et al. [17]. Rabosky's approach combines two likelihoods. The first is called the phylogenetic likelihood and uses the timing of splits along the resolved backbone of a phylogenetic tree to find maximum likelihood estimates for birth and death rates following equations developed by Nee et al. [33]. The second is called the taxonomic likelihood and uses information about the total species richness of an unresolved tip clade on a phylogeny along with the age of the split between the unresolved clade and its sister group to estimate diversification rates following methods developed by Magallon and Sanderson [34]. Rabosky et al. [17] presented a likelihood ratio test for a model where birth and death rates are allowed to shift on one branch of a phylogeny with unresolved tip clades to a model where birth and death rates are held constant across the tree. MEDUSA extends this procedure by adding rates in a stepwise fashion. First, the AIC score of a model with a single birth and death rate is calculated for the unresolved tree using the combined likelihood estimator presented by Rabosky et al. [17]. This two parameter model is then compared to the best four parameter model (two birth rates and two death rates) where the birth rate and the death rate are allowed to shift on the branch in the unresolved tree that produces the greatest improvement in the likelihood score. If the difference in AIC score between the two and four parameter models is substantial $(\triangle \mathrm{AIC} \geq 4,[35])$ then this rate shift is retained. Next the four parameter model is compared to the best six parameter model by finding the optimal place on the tree for a third rate shift. The process is continued until additional rate shifts no longer produce a substantial improvement in AIC score. Full description of MEDUSA is present in Additional file 1.

To implement MEDUSA with the actinopterygian data, first we assembled taxonomic richness data from FISHBASE [1] for major lineages of fishes. Then we pruned the timetree in Fig. 1, 2, 3 down to 27 representative lineages. Our goal in pruning down the timetree was to preserve as much of the backbone of the timetree as would still permit us to assign species richness unambiguously to tip lineages. Thus, for example, we did not retain splitting events within Percomorpha because, although it was possible to assign species richness to some percomorph subclades such as tetraodontiforms, we could not confidently assign the entire species richness of other percomorphs to lineages included in our sampling. We used this pruned 
chronogram plus the taxonomic richness to estimate birth and death rates for ray-finned fishes and tested for rate shifts across the tree in R [36] using the LASER [37] and GEIGER [38] packages.

\section{Abbreviations}

RAG1: recombination activating gene; FSGD: fish-specific whole-genome duplication event; MEDUSA: Modeling Evolutionary Diversification Using Stepwise AIC; Ma: million years ago; My: million years.

\section{Competing interests}

The authors declare that they have no competing interests.

\section{Authors' contributions}

FS and MEA contributed equally to this study and were responsible for study design, data analysis, and writing. FS downloaded and aligned sequences and assembled taxonomic richness data. FS and GC assigned fossil calibrations. MEA performed divergence time analysis. MEA and LJH performed diversification analysis. FS and GC wrote additional material. FS drew illustrations. All authors have read and approved the final manuscript.

\section{Additional material}

\section{Additional file 1}

Description of MEDUSA.

Click here for file

[http://www.biomedcentral.com/content/supplementary/1471-

2148-9-194-S1.pdf]

\section{Additional file 2}

GenBank accession numbers of sequences used in this study.

Click here for file

[http://www.biomedcentral.com/content/supplementary/1471-

2148-9-194-S2.pdf]

\section{Additional file 3}

Description of timetree calibration points.

Click here for file

[http://www.biomedcentral.com/content/supplementary/14712148-9-194-S3.pdf]

\section{Acknowledgements}

We wish to thank Alex Dornburg for his help with the preparation of $\mathrm{xml}$ files for the BEAST analyses and Tina Marcroft for help with the illustrations. The comments of three anonymous reviewers helped improve this manuscript. This research was supported in part by the National Science Foundation (NSF grants DEB 0445453 and DEB 0842397) and by a Comparative Methods in $\mathrm{R}$ Hackathon at NESCent.

\section{References}

I. FISHBASE. World Wide Web electronic publication [http:/ lwww.fishbase.org]
2. Amores A, Force A, Yan YL, Joly L, Amemiya C, Fritz A, Ho RK, Langeland J, Prince V, Wang YL, Westerfield M, Ekker M, Postlethwait $\mathrm{JH}$ : Zebrafish hox clusters and vertebrate genome evolution. Science 1998, 282:|7||-|7|4.

3. Meyer A, Peer Y Van de: From 2R to 3R: evidence for a fish-specific genome duplication (FSGD). Bioessays 2005, 27:937-945.

4. Hoegg S, Brinkmann H, Taylor JS, Meyer A: Phylogenetic timing of the fish-specific genome duplication correlates with the diversification of teleost fish. J Mol Evol 2004, 59:190-203.

5. Postlethwait J, Amores A, Cresko W, Singer A, Yan YL: Subfunction partitioning, the teleost radiation and the annotation of the human genome. Trends Genet 2004, 20:48I-490.

6. Taylor JS, Peer $Y$ Van de, Meyer A: Revisiting recent challenges to the ancient fish-specific genome duplication hypothesis. Curr Biol 200I, I I:R I005-8.

7. Hurley IA, Mueller RL, Dunn KA, Schmidt KJ, Friedman M, Ho RK, Prince VE, Yang Z, Thomas MG, Coates MI: A new time-scale for ray-finned fish evolution. Proc $R$ Soc B 2007, 274:489-498.

8. Patterson C: Osteichthyes: Teleostei. In The fossil record 2 Edited by: Benton MJ. London: Chapman \& Hall; 1993:62I-656.

9. Inoue JG, Miya M, Venkatesh B, Nishida M: The mitochondrial genome of Indonesian coelacanth Latimeria menadoensis (Sarcopterygii: Coelacanthiformes) and divergence time estimation between the two coelacanths. Gene 2005, 349:227-235.

10. Yamanoue Y, Miya M, Inoue JG, Matsuura K, Nishida M: The mitochondrial genome of spotted green pufferfish Tetraodon nigroviridis (Teleostei: Tetraodontiformes) and divergence time estimation among model organisms in fishes. Genes Genet Syst 2006, 81:29-39.

II. Azuma Y, Kumazawa Y, Miya M, Mabuchi K, Nishida M: Mitogenomic evaluation of the historical biogeography of cichlids toward reliable dating of teleostean divergences. BMC Evol Biol 2008, 8:215.

12. Vandepoele K, De Vos W, Taylor JS, Meyer A, Peer Y Van de: Major events in the genome evolution of vertebrates: paranome age and size differ considerably between ray-finned fishes and land vertebrates. Proc Natl Acad Sci USA 2004, 10 I: 1638- 1643.

13. Nelson JS: Fishes of the world. New York: John Wiley \& Sons; 2006.

14. Genner MJ, Seehausen O, Lunt DH, Joyce DA, Shaw PW, Carvalho GR, Turner GF: Age of cichlids: new dates for ancient lake fish radiations. Mol Biol Evol 2007, 24:1269-1282.

15. Alfaro ME, Santini F, Brock CD: Do reefs drive diversification in marine teleosts? Evidence from the pufferfishes and their allies (Order Tetraodontiformes). Evolution 2007, 61:2104-2126.

16. Alfaro ME, Santini F, Brock CD, Alamillo H, Dornburg A, Rabosky DL, Carnevale G, Harmon LJ: Lineage-specific Diversification Rates and High Turnover in the History of Jawed Vertebrates. Proc Natl Acad Sci U S A 2009, I06(32):134|0-134|4.

17. Rabosky DL, Donnellan SC, Talaba AL, Lovette IJ: Exceptional among-lineage variation in diversification rates during the radiation of Australia's most diverse vertebrate clade. Proc Biol Sci 2007, 274:2915-2923.

18. Crow KD, Wagner GP: Proceedings of the SMBE Tri-National Young Investigators' Workshop 2005. What is the role of genome duplication in the evolution of complexity and diversity? Mol Biol Evol 2006, 23:887-892.

19. Strathmann RR, Slatkin M: The improbability of animal phyla with few species. Paleobiology 1983, 9:97-106.

20. Ricklefs RE: Small clades at the periphery of passerine morphological space. Am Nat 2005, 165:65 I-659.

21. Lynch M, Force A: The probability of duplicate gene preservation by subfunctionalization. Genetics 2000, 154:459-473.

22. Wood R: Reef evolution. New York: Oxford University Press; 1999.

23. Hallam A: An outline of Phanerozoic biogeography. Oxford: Oxford University Press; 1994.

24. Haq BU, Hardenbol J, Vail PW: Chronology of Fluctuating Sea Levels Since the Triassic. Science 1987, 235(4793): I I56-I I67.

25. Jablonski D, Flessa KW, Valentine JW: Biogeography and paleobiology. Paleobiology 1985, I I:75-90.

26. Donoghue PCJ, Purnell MA: Genome duplication, extinction and vertebrate evolution. Trends Ecol Evol 2005, 20:3।2-319. 
27. Semon $\mathrm{M}$, Wolfe $\mathrm{KH}$ : Consequences of genome duplication. Curr Opin Genet Dev 2007, 17(6):505-5I2.

28. Scannell DR, Byrne KP, Gordon JL, Wong S, Wolfe KH: Multiple rounds of speciation associated with reciprocal gene loss in polyploid yeasts. Nature 2006, 440:34I-345.

29. Bikard D, Patel D, Le Mette C, Giorgi V, Camilleri C, Bennett MJ, Loudet O: Divergent evolution of duplicate genes leads to genetic incompatibility within A. Thaliana. Science 2009, 323(59|4):623-626.

30. Thompson JD, Higgins DG, Gibson TJ: CLUSTAL W: improving the sensitivity of progressive multiple sequence alignment through sequence weighting, positions-specific gap penalties and weight matrix choice. Nucleic Acids Research 1994, 22:4673-4680.

3I. Tamura K, Dudley J, Nei M, Kumar S: MEGA4: Molecular Evolutionary Genetics Analysis (MEGA) software version 4.0. Mol Biol Evol 2007, 24:1596-1599.

32. Drummond AJ, Rambaut A: BEAST: Bayesian evolutionary analysis by sampling trees. BMC Evol Biol 2007, 7:214.

33. Nee S, May RM, Harvey PH: The reconstructed evolutionary process. Philos Trans R Soc Lond B Biol Sci 1994, 344(1309):305-3I I.

34. Magallon $S$, Sanderson MJ: Absolute diversification rates in angiosperm clades. Evolution 200I, 55:1762-1780.

35. Burnham KP, Anderson DR: Model selection and multimodel inference, a practical information-theoretic approach. York: Springer; 2003.

36. R Development Core Team: R: A Language and Environment for Statistical Computing. 2009 [http://www.R-project.org].

37. Rabosky DL: LASER: A Maximum Likelihood Toolkit for Detecting Temporal Shifts in Diversification Rates From Molecular Phylogenies. Evol Bioinform Online 2007, 2:273-276.

38. Harmon LJ, Weir JT, Brock CD, Glor RE, Challenger W: GEIGER: investigating evolutionary radiations. Bioinformatics 2008, 24:|29-|3|.

Publish with Bio Med Central and every scientist can read your work free of charge

"BioMed Central will be the most significant development for disseminating the results of biomedical research in our lifetime. "

Sir Paul Nurse, Cancer Research UK

Your research papers will be:

- available free of charge to the entire biomedical community

- peer reviewed and published immediately upon acceptance

- cited in PubMed and archived on PubMed Central

- yours - you keep the copyright
BioMedcentral 